IJJM

Ilomata International Journal of Management

P-ISSN: 2714-8971; E-ISSN: 2714-8963

Vol. 1 No. 4 October 2020 pp.198-202

https://www.ilomata.org/index.php/iijm

\title{
Analysis of Factors That Influence Employee Performance of PT Bumimulia Indah Lestari Cilegon Banten
}

\author{
Suhartini ${ }^{1}$, Ratu Dea Mada ${ }^{2}$ \\ ${ }^{12}$ University of Serang Raya \\ Correspondent:suhartini@,unsera.ac.id
}

Submitted : October 21, 2020 Revised : October 25, 2020 Published : October 30, 2020

\begin{abstract}
This study aims to determine the factors that influence employee performance at PT. Bumimulia Indah Lestari Cilegon Banten. The independent variables Social security and work motivation are the factors that are analyzed partially and simultaneously on the Dependent Variable of Employee Performance at the company. The number of samples in this study was 70 employees is a saturated sample. The analysis technique in this research uses validity test, reliability test, classic assumption test, multiple linear regression analysis, t-test, F-test, and R2 test. The research method used is descriptive quantitative method that is measurement of object data by processing data using SPPS V.25.0 software. The results showed that (1) Social security variables partially did not have a positive and significant effect on the performance of the employees of PT Bumimulia Indah Lestari, as evidenced by the t-value of 1,458<t-table 1,668 with a sig value of $0.150>$ 0.05. (2) Work Motivation Variable partially positive and significant effect on the performance of the employees of PT Bumimulia Indah Lestari, evidenced by t-value 2,375 $>$ t- table 1,668 with a sig value of $0.02<0.05$. (3) Social Security and Work Motivation Variables simultaneously have a positive and significant effect on Employee Performance of $19.6 \% \mathrm{~s}$ on the performance of employees of PT Bumimulia Indah Lestari, where the Fcount is 8,189> F table 3.13 with a sig value of $0.001<0.05$. Suggestions for PT Bumimulia Indah Lestari pay more attention to the timeliness of employees in carrying out their work so that the company's targets are met properly.
\end{abstract}

Keywords: Social security, Work Motivation, Employee Performance

\section{INTRODUCTION}

The development of the era along with the rapid advancement of technology today, forced or voluntarily changed the pattern of life of employees and in their attitude and action. Human resources is one of the most important elements in managing a company is something that is primary, mandatory and cannot be denied anymore. Therefore, the adequacy of welfare for employees is something that is not negotiable, so that employees remain focused on working and loyal to the company. Forms of attention to employees who have been sometimes overlooked is the social security services should be provided by the company in the form of a substitute for income lost as a result or circumstances experienced by employees in the form of guarantees health, occupational accident, maternity leave, pension plan, etc. so that employee feel their needs are met, to feel safe and comfortable in the work that ultimately has the motivation high to perform the activity optimally. The phenomenon of fluctuations in performance at the company shows that employees are still not doing maximum work activities, one of which is due to low work motivation, and low attention (in the form of social security) to employees. 
In carrying out the tasks that carried out by employees at work, of course they involve risks both directly (short term) and indirectly (long term). Risks that occur include illness, minor accidents to permanent disability, even to death. So the company should pour out its policies to meet the needs of employees in the form of social security, at least the worries and fears can be avoided by employees.

In a company, not all the performance produced by employees get good results, because the level of performance of each person is different. Performance is all actions or behaviors that are controlled by individuals and contribute to the achievement of the goals of the organization. A good employee performance can lead to the survival of the company well. To obtain and improve good employee performance, the company must know and serve the needs of its employees. Not only that but also how companies provide security for employees and also improve employee welfare with social security in the company. There is a risk or uncertainty about the dangers that will occur in the company, both the work environment and the technology used makes employees feel uneasy and scared so that they are not able

Human resources is a very important factor for the company to achieve its goals. Therefore, the Company must maintain and fulfill the needs of human resources including providing social security programs. The aim is nothing else so that employees feel calm, at ease, and not worried about threats that may befall when doing their work so that they are more focused on their productivity performance to be more leverage.

The company certainly wants quality human resources and able to work optimally. No less important to improve employee performance by providing motivation can stimulate employees to move themselves more in realizing company goals.

PT Bumi Mulia Indah Lestari is a company that produces a wide range of plastic packaging that has been working together with major companies, so that the employee's performance is one that gets the attention in order to achieve the objectives of the company.

\section{METHOD}

In this research, the object of the author's research is PT Bumimulia Indah Lestari in accordance with the object under study, the writer conducts research on PT Bumimulia Indah Lestari. The focus of research is only in effect social insurance and work motivation on employee performance.

The population of this study was 234 employees. The sample according to Sugiyono (2015: 215) is part of the number and characteristics possessed by the population. Retrieval of samples in this study with probability sampling technique that is proportionate stratified random sampling using the Slovin formula. The number of samples determined by the formula is 70 respondents.

Data collection method is a method of how research data is obtained. To obtain the required data and information from this research, the following methods are used: Library Research; and Field research.

Data collection techniques are a way of how research data are obtained, data collection techniques carried out in research are as follows: Study literature, Observation, Interview, and Questionnaire. 


\section{RESULTS AND DISCUSSION}

The author needs to report the results in sufficient detail so that the reader can see which statistical analysis was conducted and why, and later to justify the conclusions. Individual hypothesis testing ( $t$ test) is used to test individually the effect of social security and work motivation on the performance of the employees of PT Bumimulia Indah Lestari. Testing the effect of each independent variable on the dependent variable can be seen in table 1 .

Table 1.

$\mathrm{T}$ Test Result

\begin{tabular}{c|c|c|c|c}
\hline $\begin{array}{c}\text { Independent } \\
\text { Variable }\end{array}$ & $\begin{array}{c}\text { T- } \\
\text { Value }\end{array}$ & $\begin{array}{c}\text { T- } \\
\text { Table }\end{array}$ & Sig & Decision \\
\hline $\begin{array}{c}\text { Social Security } \\
\text { (X1) }\end{array}$ & 1,458 & 1,668 & 0.150 & Not significant \\
\hline $\begin{array}{c}\text { Work Motivation } \\
\text { (X2) }\end{array}$ & 2,357 & 1,668 & 0.021 & Significant \\
\hline
\end{tabular}

Source: SPSS V.25.0 Data Processing

According to the table 1 above is obtained the value of t-value 1.458, further this value will be compared using 5\% significance limits and the calculation result obtained is $\mathrm{dk} \mathrm{n-3} \mathrm{(70-3} \mathrm{=} \mathrm{67)} \mathrm{then} \mathrm{obtained} \mathrm{t-table} \mathrm{1,668.} \mathrm{With} \mathrm{a} \mathrm{value} \mathrm{of} \mathrm{t-value1,458}<$ t-table 1,668 with significant values $0.150>0.05$. Obtained $t$-value is smaller than $t$-table so that $\mathrm{H} 0$ is accepted and $\mathrm{Ha}$ rejected, meaning there is a significant difference from the Social Security variable factors (X1) the Employee Performance (Y).

Based on the above table is obtained by value $t$-value to 2,357 later this value will be compared using 5\% significance limits and the calculation result obtained is $\mathrm{dk} n-3 \quad(70-3=67)$ then obtained $\mathrm{t}$ table amounted to 1,668. With the value of $\mathrm{t}$-vallue 2,357>t-table 1,668 with significant values of $0,02<0,05$. Obtained $t$-value greater than $t$-table so that $\mathrm{H} 0$ is rejected and $\mathrm{Ha}$ accepted, meaning that there is significant influence of variables Motivation (X2) on employee performance $(\mathrm{Y})$.

Simultaneous hypothesis testing (Test F) is used to test the effect of social security and work motivation on the performance of the employees of PT Bumimulia Indah Lestari can be seen in table 2.

Table 2

F-Test Results

\begin{tabular}{c|c|c|l|l}
\hline Independent variable & F-value & F-tabel & Sig & Decision \\
\hline $\begin{array}{c}\text { Social security and work } \\
\text { motivation }\end{array}$ & 8.189 & 3.13 & 0.001 & Significant \\
\hline
\end{tabular}

Source: SPSS V.25.0 Data Processing

Based on the results of the table above, the F-value is 8,189 , then this value will be compared with the F-table with a significant level of $5 \%$, the number of samples $\mathrm{N}=70$ and df numerator $(\mathrm{K}-2)$ or $(\mathrm{NK})$ or $(70-2=68)$. Then obtained the F-table of 3.13 and a significant value of $0.001<0.05$. Obtained $\mathrm{F}$-value greater than $\mathrm{F}$ table so that $\mathrm{H}_{0}$ is rejected and $\mathrm{H}_{\mathrm{a}}$ accepted, meaning that there is a significant effect of the variable (X1) and motivation (X2) on employee performance $(Y)$.

The coefficient of determination indicates what percentage and variation (rise and fall) the dependent variable can be explained or described by the various of independent variables. The determination coefficient from correlation coefficient and expressed as percentage 
Analysis of Factors That Influence Employee Performance of PT Bumimulia Indah Lestari Cilegon Banten Suhartini, Mada

Table 3

\begin{tabular}{c|ccc} 
& \multicolumn{3}{c}{ Analyze Coefficient of Determination } \\
MODEL & $\mathrm{R}$ & $\begin{array}{l}\mathrm{R} \\
\text { SQUARE }\end{array}$ & ADJUSTED R. SQUARE \\
\hline 1 & .443 & .196 & .172
\end{tabular}

From calculation above obtained value of multiple determination coeficient (R2) of 0.196 adjusted. This can mean that the Social Security variable and motivation affects $19.6 \%$ toward Employee Performance. This coefficient of determination shows the level of relationship between variables $\mathrm{X} 1$ and $\mathrm{X} 2$ to $\mathrm{Y}$ is moderate and the remaining $80.4 \%$ is influenced by other factors.

Effect of Social Security variable (X1) on Employee Performance (Y). Test results 1 show that the variable Social Security (X1) does not have a significant effect on Employee Performance $(\mathrm{Y})$. This decision was based on the results of data processing which showed a value of $1.458<\mathrm{t}$ table 1.668 with a significant value of $0.150>0,05$.

The influence of Motivation variable (X2) on Employee Performance (Y). Hypothesis 2 test results show that the Motivation variable (X2) has a significant effect on Employee Performance $(\mathrm{Y})$. This decision is based on the results of data processing which shows the value of t-test $2,375>\mathrm{t}$ table 1,668 with a significant value of 0,02<0,05.

The Effect of Social Security (X1) and Motivation (X2) on Employee Performance (Y). Based on the results of the F-Test shows that there is a significant effect of all Independent variables namely Social Security (X1) and Motivation (X2) on Employee Performance. This decision is based on the results of data processing which shows the calculated F-value of 8,189> F-table 3,13 with a significant value of $0.001<0.05$.

\section{CONCLUSION}

Social Security does not have a positive and partially significant effect on the Performance of Employees of PT Bumimulia Indah Lestari, where t-value 1,458<t-table 1,668 with sig $0,150>0,05$.

Motivation has a positive and partially significant effect on the performance of the employees of PT Bumimulia Indah Lestari, where T-count 2.375> Ttable 1.668 with a sig value of $0,02<0.05$.

Social Security and motivation positively and significantly by $19,6 \%$ simultaneously the Employee Performance PT Bumimulia Indah Lestari, where F-value 8.189> 3.13 F-table with sig $0.001<0.05$.

\section{REFERENCES}

A.S. Munandar (2001). Psikologi Industri dan Organisasi Depok : Universitas Indomesia.

Anwar Prabu Mangkunegara A.A. (2012). Manajemen Sumber Daya Manusia. Bandung: PT. Rosdakarya.

Anwar Prabu Mangkunegara A.A. (2013). Manajemen Sumber Daya Manusia Perusabaan,

Bandung : Remaja Rosdakarya.

Abraham H. Maslow. (2010). Motivation and Personality. Jakarta: Rajawali.

Asikin, Zainal. (1993). Dasar-dasar Hukum Perburuban. Jakarta : Raja Grafindo Persada.

Edison, (2016). Manajemen Sumber Daya Manusia. Bandung : Alfabeta. 
Analysis of Factors That Influence Employee Performance of PT Bumimulia Indah Lestari Cilegon Banten

Suhartini, Mada

Ghozali, Imam. (2013). Aplikasi analisis multivariate dengan program SPSS. Yogyakarta: BP universitas diponegoro edisi 7.

Irham Fahmi. (2012). Manajemen Kinerja. Jakarta.

Hasibuan Malayu S.P. (2011). Manajemen Sumber Daya Manusia,Edisi Revisi. Jakarta : Bumi aksara.

Hasibuan Malayu S.P. (2007). Manajemen Sumber Daya Manusia. Jakarta : Cetakan 9. PT. Bumi Aksara.

Husni lalu. (2003). Pengantar Hukum Ketenagakerjaan edisi revisi. Jakarta: Rajawali pers. Imam Soepomo SH, Prof, Opcit, Halaman 73.

Kansil, C.S.T. Kansil., Cristine S.T. (2002). Pokok-Pokok Hukum Jaminan Sosial Tenaga Kerja (Jamsostek) Undang-Undang No. 3 Tahun 1992. Jakarta : Pustaka Sinar Harapan.

Mathis, R.L. \& J.H. Jackson. (2006). Human Resource Management: Manajemen Sumber Daya Manusia. Terjemahan Dian Angelia. Jakarta: Salemba Empat.

Nawawi Hadari (2011) Manajemen Sumber Daya Manusia: Untuk. Bisnis Yang Kompetitif, Yogyakarta : Gajahmada University Press.

Siagian, H. (2014) Manajemen Suatu Pengantar, Alumni Bandung.

Soepomo, imam. (2005). Pengantar Hukum Perburuban Jakarta : Djambatan.

Sutrisno Edy. (2013). Manajemen Sumber Daya Manusia, Jakarta : Kencana Pernada Media Group. Wibowo. (2007). Manajemen Kinerja. Jakarta: PT. Raja Grafindo Parsada.

Sugiyono. (2015) Metode Penelitian Kuantitatif Kualitatif dan R\&D Cetakan Ke-22. Bandung :Alfabeta.

Yani, M. H. (2012). manajemen sumber daya manusia. Jakarta : Mitra Wacana Media. 